Виктор Тринчук, Татьяна Тринчук

Kijowski Państwowy Uniwersytet Ekonomii i Handlu

\title{
ДОГОВОР СТРАХОВАНИЯ КАК СПОСОБ РЕАЛИЗАЦИИ СТРАХОВЫХ ПРАВООТНОШЕНИЙ
}

Необходимость существования института страхования заложена уже в самих основах человеческого бытия. Это предопределено возможностью возникновения непредсказуемых и неотвратимых событий, характеризующихся вероятностью наступления неблагоприятных последствий. Убытки от таких событий могут быть достаточно существенными, а часто и совсем не покрываемыми за счет собственных средств физических и юридических лиц. Кроме того, дополнительные средства могут понадобиться физическим лицам в случае наступления определенных событий, которые будут угрожать их жизни, здоровью или приведут к потере работоспособности и т.д. Поэтому страхователи заинтересованы в наличии другого источника средств для компенсации убытков. Таким источником дополнительных средств физические и юридические лица (страхователи) пользуются, заключая договоры страхования с финансовыми учреждениями, которые осуществляют страховую деятельность (страховщиками).

Следовательно, особенность правоотношений, которые возникают между субъектами на рынке страховых услуг, заключается в том, что предоставление страховой услуги оформляется договором страхования. Действующее законодательство Украины дает определение понятия договора страхования в трех нормативных актах: Гражданском кодексе Украины (ст. 979), Хозяйственном кодексе Украины (ст. 354), Законе Украины «О страховании» (ст. 16). В тоже время, анализ соответствующих норм перечисленных законодательных актов, а также научной литературы не дает возможность однозначно установить отличие между договором страхования и такими документами как страховой полис и страховое свидетельство, часто применяемыми в страховой деятельности.

Данному вопросу научные работники, на удивление, уделяют мало внимания, а практическое значение он имеет весомое, поскольку в страховой практике часто полис на его юридической силе приравнивают к страховому догово- 
ру, хотя он является сокращенной формой договора страхования, содержащей только лиш основную характеристику договора. Некоторые ученые, в частности, Кинащук Л., Пацурия Н, Петров Д. считают, что даные понятия являются тождественными. Чапичадзе Я., Залетов А., Слюсаренко О., Шиминова М. настаивают на том, что страховой полис (свидетельство, сертификат) выступает юридической формой договора страхования. Шумелда Я., Осадець С., Худяков А. и др. называют договор страхования и страховой полис (свидетельство, сертификат) разными документами.

Целью статьи является выяснение особенностей юридического оформления договорных отношений в страховании. Заданиями, которые возникают в соответствии с поставленной целью являются: исследование соотношения известных в сфере страхования форм реализации страховых правоотношений; анализ определения понятий «договор страхования», «страховой полис», «страховое свидетельство», которые встречаются в законодательстве и в научной литературе; определение значения разных форм подтверждения наличия страховых правоотношений.

Большинство предложенных учеными определений договора страхования можно отнести к поверхностным, таким, которые не раскрывают сущность договора страхования. Осуществлялись и попытки закрепить в законодательстве разных государств унифицированое определение договора страхования.

Для формирования общего понятия договора страхования предлагались разные критерии. Например, как фундамент для определения общего понятия договора страхования была предложена категория имущественной потребности, которая находится в тесной взаимосвязи со страховым случаем, как источником, который ее порождает. Однако некоторые исследователи настаивали на противоположной позиции, высказываясь о нецелесообразности подобных унификаций. На наш взгляд, наиболее полным, с позиции раскрытия юридической природы договора страхования, заключающейся в особенном, самостоятельном существовании относительно других гражданско-правовых договоров, является определение договора страхования, предложенное Меером Д., которые считает, что договор страхования - это договор, в котором одно лицо, за вознаграждение или бесплатно, принимает на себя риск по любому имущественному праву, которое принадлежит другому лицу, то есть обязывается уберечь его в случае потери этого права от какого-либо несчастья ${ }^{1}$.

Сам договор страхования выполняет две основные функции. Во-первых, это юридический факт, с которым норма права связывает возникновение, из-

1 Правовое регулирование страховой деятельности в Украине: Учеб. пособие. / Чапичадзе Я.А - Х.: «Апэкс+», 2004. - C.150. 
менение или прекращение прав и обязанностей его участников. Это значит, что договор как соглашение является юридическим фактом, на основании которого возникают договорные обязательства и строятся правовые отношения. Во-вторых, поскольку стороны договора не только устанавливают между собой правовую связь, но и в определенной мере определяют его содержание, , договор является средством регулирования отношений, закрепления условий, на которых будет строиться правовая связь его участников ${ }^{2}$.

Юридическое определение договора страхования содержится в ст.16 Закона Украины «О страховании», в которой отмечается, что договор страхование это письменное соглашение между страхователем и страховщиком, согласно с которой страховщик берет на себя обязательство в случае наступления страхового случая осуществить страховую выплату страхователю или другому лицу, определенному в договоре страхования страхователем, в интересах которой заключен договор страхования (подать помощь, выполнить услугу и тому подобное), а страхователь обязывается платить страховые платежи в определенные сроки и выполнять другие условия договора ${ }^{3}$.

Договоры страхования заключаются в соответствии с правилами страхования, которые разрабатываются страховщиком для каждого вида страхования отдельно и подлежат регистрации в Уполномоченном органе при выдаче лицензии на право осуществления соответствующего вида страхования.

В ст.16 Закона Украины «О страховании», прописаны существенные условия договора страхования:

- название документа;

- название и адрес страховщика;

- фамилия, имя, отчество или название страхователя и застрахованного лица, их адреса и даты рождения;

- фамилия, имя, отчество, дата рождения или название вигодоприобретатела и его адрес;

- указание объекта страхования;

- размер страховой суммы по договору страхования;

- размер страховой суммы и (или) размеры страховых выплат по договору страхования жизни;

2 Правовое регулирование страховой деятельности в Украине: Учеб. пособие. / Чапичадзе Я.А - Х.: «Апэкс+», 2004. - С.151.

3 Про страхування: Закон України від 07.03.1996 р. із змінами та доповненнями [Електронний ресурс]. - Режим доступу: http://meget.kiev.ua/zakon/zakon-o-strahovanii/razdel-2/ 
- перечень страховых случаев;

- размеры страховых взносов (платежей, премий) и сроки их уплаты;

- страховой тариф (страховой тариф не определяется для страховых случаев, для которых не устанавливается страховая сумма);

- срок действия договора;

- порядок изменения и прекращения действия договора;

- условия осуществления страховой выплаты;

- причины отказа в страховой выплате;

- права и обязанности сторон и ответственность за невыполнение или неподобающее выполнение условий договора;

- другие условия при согласии сторон;

- подписи сторон ${ }^{4}$.

Уполномоченный орган имеет право устанавливать дополнительные требования к договорам страхования жизни и договоров страхования имущества граждан.

В соответствии с международными системами страхования, которые требуют применения унифицированных условий страхования, договоры страхования заключаются с учотом указанных условий страхования, а также требований, предусмотренных Законом.

Уполномоченный орган устанавливает требования к порядку заключения договоров со страховщиками-нерезидентами.

Для заключения договора страхования страхователь подает страховщику письменное заявление по форме, установленной страховщиком, или иным образом заявляет о своем намерении заключить договор страхования. При заключении договора страхования страховщик имеет право запросить от страхователя баланс или справку о финансовом состоянии, подтвержденные аудитором (аудиторской фирмой), и другие документы, необходимые для оценки страховщиком страхового риска.

Факт заключения договора страхования может быть подтвержден страховым свидетельством (полисом, сертификатом), которое является формой договора страхования (ст. 18 Закона Украины «О страховании»).

4 Про страхування: Закон України від 07.03.1996 р. із змінами та доповненнями [Електронний ресурс]. - Режим доступу: http://meget.kiev.ua/zakon/zakon-o-strahovanii/razdel-2/ 
Договор страхования вступает в силу с момента внесения первого страхового платежа, если иное не предусмотрено договором страхования.

Договор страхования жизни может быть заключен как путем составления одного документа (договора страхования), подписанного сторонами, так и путем обмена листами, документами, подписанными стороной, которая их посылает. В случае предоставления страхователем письменного заявления по формое, установленной страховщиком, что выражает намерение заключить договор страхования, такой договор может быть заключен путем высылания страхователю копии правил страхования и выдачи страхователю страхового свидетельства (полиса), который не содержит разногласий с поданным заявлением. Заявление подается в двух экземплярах, копия заявления высылается страхователю с отметкой страховщика или его уполномоченного представителя о принятии предложенных условий страхования.

Из этого следует, что Закон называет свидетельство, полис и сертификат разновидностями юридического удостоверения факта заключения договора, отождествляя их между собой, но не с самим договором страхования. Следует обратить внимание и на интересное словосочетание «факт заключения договора может удостоверяться», то есть и даном случает отсутствует императивность, которая бы обеспечивала обязательное наличие страхового свидетельства. Следовательно, страховой полис (свидетельство, сертификат) и договор страхования являются разными документами.

В соответствии со ст. 981 Гражданского кодекса Украины, договор страхования заключается в письменной форме и может заключаться путем выдачи страховщиком страхователю страхового свидетельства (полиса, сертификата) 5 .

В случае несоблюдения письменной формы договора страхования такой договор является ничтожным.

Письменная форма обязательна для всех договоров страхования. Различают два способа заключения договора страхования: путем составления одного документа, который подписывается сторонами и путем выдачи страховщиком страхователю страхового свидетельства (полиса, сертификата), который фактически удостоверяет факт заключения договора. Страховые полисы и свидетельства, как правило, содержат все условия договора, включая стандартные правила страхования, специальные условия для данного договора, дополнения и исключения из стандартных правил; в них могут содержаться индивидуальные, отдельно согласованные со страхователем условия ${ }^{6}$.

\footnotetext{
5 Цивільний кодекс України від 16.01.2003 р. із змінами та доповненнями [Електронний ресурс]. - Режим доступу: http://meget.kiev.ua/kodeks/grazdanskiy-kodeks/glava-67/

6 Науково-практичний коментар до Цивільного кодексу України: Харитонов Є.О., Харитонова О.І., Голубєва Н.Ю. - К.: «Правова єдність», 2008. - С.533.
} 
Страховой полис может быть выдан страхователю на основании его письменного или устного заявления. Устного заявления достаточно, когда условия страхового обеспечения не требуют подробной информации, а страхователю известны обстоятельства, которые имеют существенное значение для определения вероятности наступления страхового случая. Таким способом заключаются краткосрочные договоры страхования от несчастных случаев, например, на время авиаперелета, договоры страхования садовых домиков и др. Положения статьи 981 Гражданского кодекса Украины не лишают страховщика права требовать от страхователя письменного заявления.

В страховой практике существуют два вида полисов: разовый и генеральный. Разовый полис применяется при оформлении простых операций по страхованию (с одним предметом). Генеральный полис распространяется на несколько однородных операций страхования имущества относительно группы предметов). Страхование по генеральному полису осуществляется при соблюдении некоторых правил: предметом страхования должно быть имущество; это имущество должно состоять из партий; условия страхования для однородного имущества должны быть подобными; договор должен быть заключен на определенный срок. Страховые сертификаты проще. В них содержатся лишь существенные условия договора, а в остальном они отсылают к стандартным правилам страхования ${ }^{7}$.

Статья 354 Хозяйственного кодекса Украины закрепляет положение о том, что по договору страхования страхователь обязуется в случае наступления страхового случая осуществить страховую выплату страхователю или другому лицу, определенному страхователем в договоре страхования, а страхователь обязуется платить страховые платежи в определенные сроки и выполнять другие условия договора.

Орган государственной власти, уполномоченный осуществлять надзор за страховой деятельностью, имеет право соответственно закону устанавливать дополнительные требования к договорам страхования.

При заключении договора страхование страхователь имеет право требовать у страхователя справку о его финансовом состоянии, подтвержденную аудитором (аудиторской организацией).

Заключение договора страхования может удостоверяться страховым свидетельством (полисом, сертификатом), которые является формой договора страхования ${ }^{8}$.

7 Науково-практичний коментар до Цивільного кодексу України: Харитонов Є.О., Харитонова О.І., Голубєва Н.Ю. - К.: «Правова єдність», 2008. - С.533.

8 Господарський кодекс України від 16.01.2003 р. із змінами та доповненнями [Електронний ресурс]. - Peжим доступу: http://www.jobs.ua/pravo/economy-code/part6/ 
Таким образом, анализируя положение Гражданского кодекса Украины и Хозяйственного кодекса Украины, опять наблюдаем неоднозначность понимания сути понятий «договор страхования», «страховое свидетельство», «полис», «сертификат».

Некоторые научные работники подходят к значению полиса в страховой деятельности иначе. Например, Осадець С. отмечает, что для письменного признания договора страхования необходимо не только письменное заявление страхователя, но и письменное согласие страховой организации на заключение такого договора, подтверждением которой является страховое свидетельство (страховой полис), выданное страховщиком 9 .

Более детально вопрос разграничения договора страхования и страхового полиса осветил в своих работах Шумелда Я., который акцентирует внимание на том, что в связи с невещественной формой страхового продукта и длительностью страховой защиты предоставления страховых услуг документируется. Главной целью документирования является подтверждение страховых взаимоотношений и определение обязанностей и прав сторон. Для этого в страховой практике традиционно применяется два вида документов - страховой договор и страховой полис (свидетельство, сертификат). На начальных этапах развития страхования применялся страховой полис. В процессе развития страховых отношений он расширялся и постепенно превратился в страховой договор. Понятия «страховой договор» и «страховой полис» является тождественным, по сути и назначению между ними разницы нет, однако существует разница по их содержанию ${ }^{10}$.

В современной зарубежныой страховой практике страховой договор рассматривается как письменный документ, в котором детально раскрываются все условия и порядок осуществления страховых отношений по поводу страхования определенного объекта. Страховой полис является сокращенной формой договора страхования, которая содержит только основную характеристику договора. Другие общие или стандартные условия договора в полисе, как правило, отсутствуют, потому к нему всегда добавляются извлечения из правил того вида страхования, на основании которого заключен договор.

Применение страхового договора и страхового полиса, их структура регулируются гражданским и страховым законодательством. Основным и первоочередным документом, согласно Закону Украины «О страховании», является именно договор страхования. В украинской практике страхования договор применяется в добровольных, а страховой полис - по большей части в обяза-

9 Страхування: Підручник / Осадець. С.С. - Вид. 2-ге, перероб. і доп. - К.: КНЕУ, 2002. - С.236.

10 Страхування: Навчальний посібник / Шумелда Я. П. - Видання друге, розширене. - К.: Міжнародна агенція «Б|ЗОН», 2007. - C.80-81. 
тельных видах страхования. Закон Украины «О страховании» позволяет применять страховой полис с дополнением правил страхования только при страховании жизни, когда страхователь подает письменное заявление по форме, установленной страховщиком, а ему вместо договора выдается полис ${ }^{11}$.

Исследуя данный вопрос, целесообразно обратиться к толкованию даных понятий в словарях и энциклопедиях. Так, Энциклопедия страхования отождествляет эти понятия. Полис (страховой договор, страховое свидетельство) (policy) - письменное соглашение между страхователем и страховщиком, которое удостоверяет факт того, что страховщик в случае наступления страхового случая берет на себя обязательство выплатить страховую сумму или в пределах страховой суммы возместить убыток страхователю или другому лицу, указанному в полисе, при условии уплаты страховых платежей в определенные сроки. Полис должен содержать: название документа, реквизиты страховщика, фамилию или название страхователя, его адрес, перечень объектов страхования, размер страховой суммы, перечень страховых случаев, размер тарифа, а также страховых платежей, срок их уплаты, срок действия договора, права и обязанности сторон, другие условия, подписи сторон ${ }^{12}$.

Он-лайн словарь дает такое определение понятия «полис», полис (англ. policy) - документ, который подтверждает заключение договора страхования. Полис выдается страховщиком страхователю после заключения между ними соглашения ${ }^{13}$.

Толковый словарь русского языка под ред. Ушакова Д. предлагает следующую формулитровку, «полис» (фр. police) - окумент о застраховании (жизни, имущества от огня и т.п.). В толковом словаре под ред. Ожегова С. и Шведовой Н. «полис» ороеделяется как документ о страховании, а в словаре иностранных слов под термином «полис» (фp. police, ит. polizza расписка, квитанция) понимается свидетельство, выдаваемое страховым обществом лицу или учреждению, застраховавшему в нем что-либо, и содержащее условия заключенного договора о страховании ${ }^{14}$.

Польский ученый Шилковская В. под понятием страхового договора понимает письменный документ, согласно которому клиент получает страховую защиту. При етом полис легитимизует страховые правоотношения ${ }^{15}$.

\footnotetext{
11 Страхування: Навчальний посібник / Шумелда Я. П. - Видання друге, розширене. - К.: Міжнародна агенція «БІЗОН», 2007. -C.82.

12 Енциклопедія страхування / В.В.Фещенко та інші. - Київ.: Українське агентство фрінансового розвитку, 2008. - С.194c.

13 Он-лайн словник. [Електронний ресурс]. - Режим доступу: http://invivio.net/ua-dict/92/

14 Полис [Електронний ресурс]. - Режим доступу: http://poiskslov.com/word/полис/

15 Ubezpieczenia. Pod redakcja Wandy Sulkowskiej. - Krakow: Akademia Ekonomiczna w Krakowie, 2007. - p.48.
} 
Гражданский кодекс Российской Федерации предусматривает положение о том, что письменная форма договора может обеспечиваться разными способами: 1) путем составления одного документа, подписанного сторонами; 2) путем вручения страховщиком страхователю страхового свидетельства (полиca, сертификата, квитанции); 3 ) путем обмена документами между сторонами в любом обусловленном виде связи, которая позволила бы достоверно установить, что документ возник в процессе волеизъявления сторон договора страхования ${ }^{16}$. Нас интересует именно второй способ, который заключается в том, что на основании заявления клиента (письменного, устного) страховщик вручает ему страховой полис (свидетельство сертификат, квитанцию). Принятие настоящего документа заявителем означает его согласие на заключение договора страхования на условиях полиса. Перед вручением настоящего документа заявителю страховщик обязан ознакомить его с условиями, на которых предлагается подписать соглашение. Выдача страхового полиса (свидетельства сертификата, квитанции) подтверждает факт заключения договора страхования между страхователем и страховщиком. Поэтому очевидным является то, что страховой полис совмещает в себе значение документа, который придает договору письменную форму, выражает согласие страховщика на предложение страхователя заключить договор страхования и является доказательством заключения страхового договора. Сложно не согласиться с Худяковым А., что полис по своей сути является юридическим долговым удостоверением обязательств сторон договора: страхователя - по уплате страховых взносов, страховщика - по выплате, согласно договору, страхового возмещения.

В Российской Федерации страховой полис может заменять договор страхования выступая как «страховой полис» или как «генеральный полис».

Аналогичная ситуация сложилась в законодательстве Республики Беларусь. Договор страхования может быть заключен путем составления документа или вручения страховщиком страхователю на основе его письменного или устного заявления страхового полиса (свидетельства, сертификата), который подписан страховщиком. В этом случае согласие страхователя заключить договор на предложенных условиях подтверждается получением от страховщика указанных документов ${ }^{17}$.

Таким образом, на основании вышеизложенного можно сделать ряд выводов.

Договор страхования - это правовая форма, при которой одна из сторон (страховщик) в обмен на установленный страховой взнос обязывается в случае

\footnotetext{
16 Теория страхования / Худяков А. И. - М.: «Статут», 2010. - С. 507.

17 Страхование на транспорте: Учеб. пособие для студентов высших учеб. заведений / А.Я. Андреев и др. Минск: ИВЦ Минфина, 2009. - С.14.
} 
наступления страхового случая и соблюдения условий договора осуществить другой стороне (страхователю, застрахованному, выгодоприобретателю) страховую выплату.

На сегодняшний день и в законодательстве, и в научной литературе отсутствует единство в толковании формы реализации страховых правоотношений. Отечественному страховому рынку присуща неоднозначность относительно трактовки понятий «договор страхования», «страховой полис», «страховое свидетельство», «страховой сертификат».

Закон Украины «О страховании» называет свидетельство, полис и сертификат разновидностями юридического удостоверения факта заключения договора, отождествляя их между собой, но не с самим договором страхования. Следует указать на отсутствие императивности, которая бы обеспечивала обязательное наличие страхового свидетельства, так как законом допускается удостоверение факта заключения договора с помощью полиса.

Страховой полис является специфическим документом даже по своему названию, который используется исключительно в страховании и к которому, согласно действующему законодательству Украины не выдвигаются существенные требования, в отличие от страхового договора. Не взирая на то, что факт заключения страхового договора может удостоверяться страховым свидетельством (полисом, сертификатом), в ходе исследования мы пришли к заключению, что договор страхования и страховой полис являются разными документами.

\section{БИБЛИОГРАФИЯ}

1. Енциклопедія страхування / В.В.Фещенко та інші. - Київ.: Українське агентство фінансового розвитку, 2008.

2. Науково-практичний коментар до Цивільного кодексу України: Харитонов С.О., Харитонова О.І., Голубєва Н.Ю. - К.: «Правова єдність», 2008.

3. Правовое регулирование страховой деятельности в Украине: Учеб. пособие. / Чапичадзе Я.А - Х.: «Апэкс+», 2004.

4. Страхование на транспорте: Учеб. пособие для студентов высших учеб. заведений / А.Я. Андреев и др. - Минск: ИВЦ Минфина, 2009.

5. Страхування: Навчальний посібник / Шумелда Я. П. - Видання друге, розширене. - К.: Міжнародна агенція «БІЗОН», 2007.

6. Страхування: Підручник / Осадець. С.С. - Вид. 2-ге, перероб. і доп. - К.: КНЕУ, 2002.

7. Теория страхования / Худяков А. И. - М.: «Статут», 2010.

8. Ubezpieczenia. Pod redakcja Wandy Sulkowskiej.-Kraków: Akademia Ekonomiczna w Krakowie, Kraków 2007. 
The theoretical aspects of the registration of insurance contracts are considered in this article, and their correlation with such concepts as an "insurance policy", "insurance certificate" and the role of these documents in insurance activity. Due attention is gived to the substantial conditions of the insurance contract in accordance with the Law of Ukraine about insurance, the Economic code and the Civil code.

Key words: insurance contract, insurance policy, certificate of insurance, substantial conditions of the insurance contract 